\title{
INTENSIFIKASI PENGETAHUAN PAJAK PADA RELAWAN PAJAK
}

\author{
Moh. Faisol ${ }^{1)}$, Isnani Yuli Andini ${ }^{2)}$ \\ ${ }^{1,2)}$ Fakultas Ekonomi dan Bisnis Universitas Wiraraja \\ Email: faisol114@wiraraja.ac.id ${ }^{1)}, \underline{\text { lia@ wiraraja.ac.id }}^{2)}$
}

\begin{abstract}
ABSTRAK
Reformasi di bidang perpajakan telah banyak dilakukan oleh Direktorat Jenderal Pajak, namun tidak sepenuhnya merubah kondisi masyarakat untuk sadar dan taat dalam memenuhi kewajiban perpajakan. Tingkat kepatuhan masyarakat masih rendah, sehingga penerimaan dari sektor pajak juga masih berlum sesuai harapan. Terobosan baru yang dilakukan oleh Dirjen Pajak adalah membentuk Tax Center dan merekrut Relawan Pajak untuk turut serta dalam mengajak dan membantu masyarakat untuk memenuhi kewajibannya, khususnya melapor pajak. Relawan Pajak tersebut belum memiliki kemampuan kerelawanan dan perpajakan yang mumpuni, sehingga butuh intensifikasi pengetahuan yang mumpuni supaya tugas relawan pajak benar-benar tepat sasaran. Intensifikasi Pengetahuan perpajakan kepada 14 orang Relawan Pajak di Tax Center Universitas Wiraraja akan dilakukan dalam bentuk pelatihan dengan rangkaian kegiatan, antara lain adalah sosialisasi, penyusunan modul relawan pajak, penyiapan sarana dan prasarana, pelatihan relawan pajak, kegiatan kerelawan, dan evaluasi. Hasil kegiatan pelatihan menunjukkan terdapat peningkatan pengetahuan relawan pajak sebelum dan sesudah pelatihan. Hasil ini diperoleh dari penyebaran angket sebanyak 30 pernyataan dengan hasil rata nilai pengetahuan relawan pajak sebelum pelatihan sebesar 3,51 sedangkan setelah mengikuti pelatihan sebesar 4,28.
\end{abstract}

Kata Kunci: Intensifikasi Pengetahuan Pajak, Relawan Pajak.

\section{Pendahuluan}

Penerimaan pajak merupakan salah satu unsur vital dalam Rencana Anggaran Belanja dan Penerimaan Negara (RAPBN), hal ini disebabkan $\pm 85 \%$ sumber penerimaan berasal dari pajak. Pajak merupakan iuran wajib masyarakat yang harus dibayarkan kepada negara, baik melalui pemerintah pusat ataupun pemerintah daerah yang bersifat memaksa bagi yang tidak patuh (Resmi, 2019) dan (Waluyo, 2017). Kewajiban pajak adalah kewajiban melekat bagi setiap warga negara yang sudah memenuhi kualifikasi untuk membayar pajak, dalam rangka turut membatu pemerintah untuk membangun negara dan mensejahterakan masyarakat.

Reformasi birokrasi dilakukan oleh Direktorat Jenderal Pajak (Dirjen Pajak) untuk meningkatkan penerimaan negara dari sektor pajak, antara lain adalah penyederhanaan peraturan perpajakan, peluncuran aplikasi, dan sosialisasi perpajakan ke khalayak umum, baik mulai sekolah dasar sampai ke perguruan tinggi melalui kegiatan salah satunya adalah inklusi kesadaran pajak. Selain itu, dalam rangka menunjang misi tersebut Dirjen Pajak melakukan kerjasama dengan perguruan tinggi terkait dengan pembentukan Tax Center, dan pada akhirnya melahirkan relawan pajak di setiap Tax Center di berbagai perguruan tinggi, sebagaimana tertuang dalam Nota Kesepahaman Menteri Keuangan dengan Menteri Riset, Teknologi, dan Pendidikan Tinggi Nomor MoU-4/MK.03/2016 dan Nomor 7/M/NK/2016, tentang Peningkatan Kerja Sama Perpajakan.

Relawan pajak sebagaimana tersebut di atas akan memiliki tugas dan fungsi untuk 
melakukan pendampingan kepada wajib pajak, baik secara personal maupun kelompok dalam melaksanakan kewajiban perpajakan, khususnya adalah pelaporan pajak. Tax Center Universitas Wiraraja merupakan salah satu perguruan tinggi yang memiliki relawan pajak sebanyak 14 orang mahasiswa relawan pajak. Sebanyak 14 orang mahasiswa yang menjadi relawan pajak seyogyanya memiliki pengalaman kerelawanan yang mumpuni dan pengetahuan perpajakan yang baik, sehingga tugas dan fungsi tersebut dapat terlaksana sesuai dengan harapan bersama.

Relawan pajak di Tax Center Universitas Wiraraja berasal dari beberapa fakultas yang ada di Universitas Wiraraja, sehingga tingkat pengetahuan tentang pajak masih relatif rendah. Mengingat, mereka di fakultas (prodinya) tidak pernah menempuh mata kuliah perpajakan, walaupun ada mata kuliah perpajakan (bagi yang berasal dari fakultas ekonomi dan bisnis) mereka juga masih belum mengambil mata kuliah perpajakan. Alhasil, dibutuhkan intensifikasi pengetahuan tentang kegiatan kerelawanan dan pengetahuan perpajakan bagi Relawan Pajak di Tax Center Universitas Wiraraja.

Adanya intensifikasi pengetahuan relawan pajak tentang kerelawanan dan pengetahuan perpajakan akan mampu memberikan nilai tambah berupa (1) pengetahuan relawan pajak yang matang, sehingga melakukan pendampingan kepada wajib pajak dapat maksimal dan wajib pajak tidak ragu untuk didampingi melaporkan pajaknya; (2) wajib pajak tidak perlu melakukan konsultasi perpajakan kepada Kantor Pajak (KPP atau KP2KP), karena sudah ada Relawan Pajak; dan (3) misi meningkatkan tingkat kesadaran dan kepatuhan wajib pajan akan tercapai sehingga berdampak pada penerimaan negara. Dengan demikian, maka dilakukanlah pengabdian kepada masyarakat untuk menyelesaikan permasalahan tersebut di atas intensifikasi relawan pajak dalam bentuk pelatihan.

\section{Metode}

Relawan Pajak di Tax Center Universitas Wiraraja yang baru saja direkrut memiliki beberapa permasalahan sebagaimana telah diuraikan di atas, antara lain (1) pengetahuan tentang kegiatan kerelawanan masih minim; (2) pengetahuan tentang pajak masih lemah, karena sebelumnya belum pernah belajar pajak secara khusus, di samping juga mahasiswa yang direktut adalah bukan mahasiswa dari Fakultas Ekonomi dan Bisnis. Untuk mengatasi masalah tersebut, terdapat beberapa metode dan tahapan yang dapat dilakukan agar keberadaan relawan pajak sesuai dengan yang diharapkan, antara lain adalah sebagai berikut.

a. Melakukan sosialisasi tentang tugas dan fungsi relawan pajak

Sebanyak 14 orang mahasiswa relawan pajak dikumpulkan dalam ruangan dan diberikan pengarahan kepada mereka tentang pentingnya tugas dan fungsi relawan pajak.

b. Menyusun modul relawan pajak

Sebagai salah satu media untuk melakukan transfer knowledge kepada 14 orang mahasiswa relawan pajak dan membantu proses pelatihan (tahap 4), maka perlu disusun modul relawan pajak. Adapun materi yang perlu ada di dalam modul tersebut adalah hakekat relawan, pelayanan prima (excellence service), hak dan kewajiban wajib pajak, pajak umum, dan pelaporan pajak (case study). 


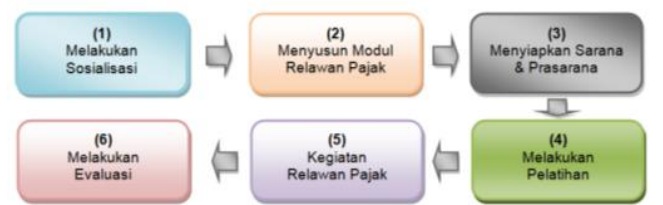

Gambar 1.1 Metode \& Tahapan Penyelesaian Masalah

\section{c. Menyiapkan sarana dan prasarana}

Sebelum dilakukan pelatihan relawan pajak, diperlukan sarana dan prasana yang akan menunjang kegiatan tersebut, antara lain persiapan undangan (pemberitahuan) kepada 14 orang mahasiswa relawan pajak, tempat pelatihan, dan akomodasi pelatihan.

d. Melakukan pelatihan relawan pajak

Pelatihan relawan pajak setidaknya dilakukan dalam kurun waktu 3 hari di dalam ruangan tertutup dengan di dukung fasilitas berupa bangku, meja, laptop, LCD Projector, Pointer, Slide (PPT), modul relawan pajak, dan jaringan internet. Pada tahap ini, 14 orang relawan pajak akan dilatih tentang hakekat relawan, pelayanan prima (excellence service), hak dan kewajiban wajib pajak, pajak umum, dan pelaporan pajak (case study).

e. Kegiatan relawan pajak

Berbekal pengetahuan yang diperoleh pada saat pelatihan (tahap 4), relawan pajak melakukan pendampingan kepada wajib pajak untuk memenuhi kewajiban perpajakannya, khususnya pelaporan pajak.

\section{f. Melakukan Evaluasi}

Evaluasi dilakukan untuk menilai, apakah penyelesaian masalah yang dilakukan ini sudah efektif atau tidak, dan lain-lain.

\section{Hasil dan Pembahasan}

Pengabdian masyarakat dengan judul intensifikasi pengetahuan pajak relawan pajak diikuti oleh seluruh relawan pajak yang ada di Tax Center Universitas Wiraraja sebanyak 14 orang relawan pajak. Relawan pajak tersebut berasal dari beberapa prodi yang ada di Universitas Wiraraja, dengan rincian sebagai berikut.

Tabel 1.1 Relawan Pajak

\begin{tabular}{|c|l|c|}
\hline No. & \multicolumn{1}{|c|}{ Program Studi } & Jumlah Relawan \\
\hline 1 & Akuntansi & 8 orang \\
\hline 2 & Manajemen & 2 orang \\
\hline 3 & Agribisnis & 3 orang \\
\hline 4 & Administrasi Publik & 1 orang \\
\hline
\end{tabular}

Jumlah relawan terbanyak berasal dari Fakultas Ekonomi dan Bisnis sebanyak 10 orang relawan pajak, yang terdiri dari program studi akuntansi sebanyak 8 orang dan program studi manajemen sebanyak 2 orang. Hal ini merupakan representasi bahwa pengetahuan perpajakan lebih dekat dengan mahasiswa akuntansi sehingga mayoritas relawan pajak berasal dari akuntansi. Di sisi lain, relawan pajak juga berasal dari Fakultas Pertanian dan Fakultas Ilmu Sosial dan Ilmu Politik dengan jumlah relawan pajak sebanyak 4 orang.

Kondisi asal usul relawan pajak yang berasal dari berbagai fakultas yang ada di Universitas Wiraraja tentunya memiliki dampak pada pengetahuan mereka sebagai relawan pajak. Mengingat ada beberapa fakultas yang kurikulumnya tidak terdapat mata kuliah perpajakan sehingga pengetahuan mereka tentang pajak dapat dikatakan minim. Begitupun dengan beberapa program studi yang terdapat mata kuliah perpajakan, namun mahasiswa yang menjadi relawan pajak belum menempuh mata kuliah perpajakan.

Atas dasar itulah, intensifikasi pengetahuan pajak pada relawan pajak adalah tepat untuk melakukan akselerasi pengetahuan mereka yang notabane nya belum pernah belajar pajak. Pengetahuan pajak relawan pajak tentunya akan memiliki memberikan tingkat yang sama antara mereka yang sudah memiliki pengetahuan pajak ataupun yang belum pernah 
sama sekali memperoleh pemahaman tentang pajak.

Intensifikasi pengetahuan pajak pada relawan pajak tersebut dilaksanakan di Universitas Wiraraja pada tanggal 12-14 Juni 2019 dengan rangkaian kegiatan sebagai berikut.

Tabel 1.2 Kegiatan Intensifikasi

\begin{tabular}{|c|l|l|}
\hline Waktu & \multicolumn{1}{|c|}{ Kegiatan } & Keterangan \\
\hline \multirow{2}{*}{ 12 Juni } & $\begin{array}{l}\text { Penyampaian materi I: } \\
\text { Pelayanan Prima } \\
\text { (excellent service) } \\
\text { Hakekat Relawan Pajak }\end{array}$ & $\begin{array}{l}\text { Isnani Yuli } \\
\text { Andini }\end{array}$ \\
\hline \multirow{2}{*}{ 13 Juni } & $\begin{array}{l}\text { Penyampaian materi II: } \\
\text { Pengantar perpajakan } \\
\text { Pajak penghasilan }\end{array}$ & Moh. Faisol \\
& Umum & \\
\hline \multirow{5}{*}{ 14 Juni } & $\begin{array}{l}\text { Penyampaian materi } \\
\text { 2019 }\end{array}$ & Moh. Faisol \\
& $\begin{array}{l}\text { Pelaporan SPT 1770 } \\
\text { S/SS } \text { online }\end{array}$ & KP2KP \\
& Simulasi Pelaporan & Sumenep \\
& SPT 1770 S/SS online & \\
\hline
\end{tabular}

Materi yang disampaikan pada kegiatan pelatihan intensifikasi relawan pajak dibagi menjadi tiga tahapan (lih. Tabel 1.2). Ketiga tahapan tersebut disampaikan selama 3 hari berturut-turut dengan melibatkan dosen dan praktisi pajak sebagai pematerinya. Secara detail kegiatan tersebut akan dijelaskan sebagai berikut.

Tahap pertama, pelayanan prima dan hakekat relawan pajak. Materi ini disampaikan oleh Isnani Yuli Andini yang menjelaskan tentang tata cara pelayanan prima yang diberikan oleh relawan pajak pada saat asistensi dan memberikan konsultasi kepada masyarakat banyak sesuai dengan standar pelayanan yang ada di kantor pajak. Relawan pajak diharapkan akan mampu memberikan eksistensi secara baik dan sesuai dengan standar pelayanan yang berlaku di Kantor
Pajak. Mampu memberikan kesan positif bagi masyarakat dalam kegiatan asistensi dan berharap masyarakat mampu memperoleh informasi secara akurat dan nyaman sehingga mereka mampu memberikan kontribusi dengan taat dan patuh pada kewajiban pajak mereka masing-masing.

Selanjutnya pada tahap pertama, relawan pajak juga diberikan materi tentang hakekat relawan pajak. Di mana relawan pajak diberikan bekal bahwa seorang relawan pajak diberikan tugas oleh Direktorat Jenderal Pajak untuk memberikan asistensi dalam rangka meningkatkan ketaatan dan kepatuhan wajib pajak tanpa memungut atau menerima bayaran. Sebagai seorang relawan, mereka memiliki kewajiban untuk mengabdi kepada negara dengan cara memberikan edukasi dan sosialisasi bahkan pendampingan kepada wajib pajak.

Tahap kedua, pengantar perpajakan dan pajak pengahsilan. Pengantar perpajakan merupakan materi yang disampaikan oleh Moh. Faisol dengan menjelaskan sejarah perpajakan, fungsi pajak, jenis pajak, sistem pemungutan pajak, teori-teori pemungutan pajak serta tarif pajak. Materi tersebut akan memberikan bekal kepada relawan pajak tentang asal usul kenapa masyarakat wajib memenuhi kewajiban perpajakan dan manfaat pajak bagi masyarakat. Sementara pajak penghasilan menjelaskan tentang pajak penghasilan yang dikenakan kepada subjek pajak orang pribadi, meliputi pengertian pajak penghasilan, objek pajak, subjek pajak, tarif pajak, serta tata cara pelaporan pajak baik secara online ataupun manual. Fokus dari pajak penghasilan yang dibahas pada kegiatan ini adalah pajak penghasilan orang pribadi yang menggunakan formulir $1770 \mathrm{~S}$ dan 1770 SS. 


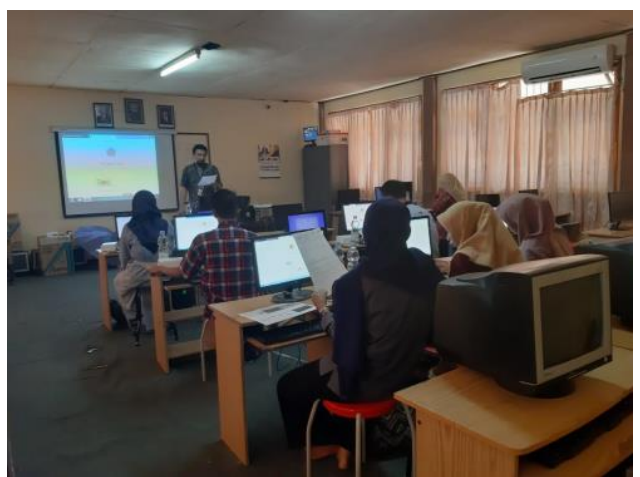

Gambar 1.2 Kegiatan Intensifikasi

Tahap ketiga, pelaporan dan simulasi pelaporan SPT 1770 S /1770 SS. Materi ini disampaikan oleh Dimas perwakilan dari Kantor Pelayanan, Penyuluhan, dan Konsultasi Perpajakan (KP2KP) Sumenep, dengan memberikan bekal kepada relawan pajak tata cara pengisian SPT 1770 S/ 1770SS secara online mulai dari login di halaman e-filing sampai pada tahap akhir pelaporan SPTnya. Pada isian SPT relawan pajak juga harus memahami terkait dengan sumber penghasilan, PTKP (penghasilan tidak kena pajak), asset dan kewajiban wajib pajak yang harus dilaporkan dalam SPT tersebut. Hal ini penting karena para relawan memiliki kewajiban untuk melakukan asistensi kepada wajib pajak khususnya pada saat melakukan pelaporan SPT Tahunan bagi wajib pajak orang pribadi. Keberadaan simulasi tentang pengisian SPT akan memberikan pemahaman yang lebih, mengingat terkait pelaporan pajak syarat dengan praktik. Kemahiran dan kemampuan pelaporan pajak secara praktik memiliki dampak besar pada kualitas mereka sebagai relawan pajak saat melakukan asistensi.

Lebih lanjut sebagai alat untuk melakukan evaluasi atas keberhasilan kegiatan tersebut pengabdi melakukan penilaian atas tingkat pemahaman peserta sebelum dan sesudah melakukan kegiatan ini. Sebelum melakukan kegiatan pengabdi memberikan kuisioner secara online (lih. Gambar 1.3) kepada relawan pajak untuk mengetahui tingkat pemahamannya tentang kegiatan relawan dan pajak. Kusioner tersebut terdiri dari 6 indikator dengan masing-masing indikator terdiri dari 5 pernyataan.

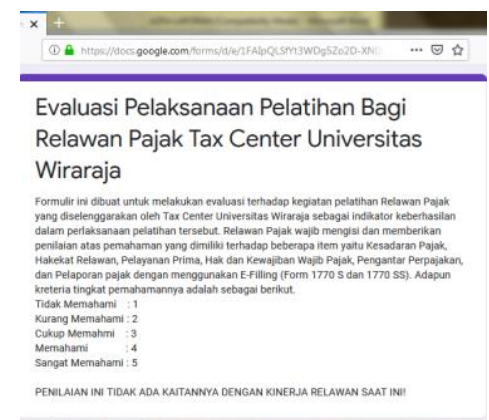

Gambar 1.3 Kuisioner secara online

Adapun indikator-indikator tersebut adalah kesadaran pajak, hakekat relawan, pelayanan prima, hak dan kewajiban wajib pajak, pengantar perpajakan, Pelaporan Pajak dengan Formulir SPT 1771 SS dan SPT 1771 SS secara online.

Hasil dari penyebaran kuisioner tersebut dapat digambarkan pada gambar 1.4 berikut ini.

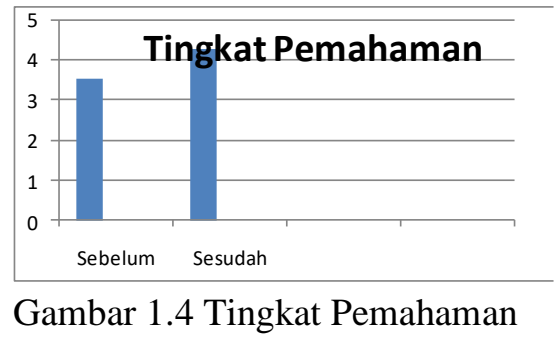

Dari tabel tersebut dapat dijelaskan bahwa pengetahuan relawan pajak sebelum dan sesudah mengikuti kegiatan intensifikasi mengalami perbedaan. Di mana sebelum melakukan intensifiksi tingkat pemahaman relawan pajak berada pada nilai rata-rata 3,51 dari 30 pernyataan yang dijawab oleh relawan pajak, sedangkan setelah mengikuti kegiatan intensifikasi memiliki nilai rata-rata 4,28.

Penilaian tingkat pemahaman tersebut menggunakan skala likert untuk melakukan 
konversi dari data kualitatif menjadi kuantitatif sehingga dapat diperbandingkan. Selisih hasil perbandingan sebesar 0,77 menunjukkan bahwa terdapat peningkatan pemahaman relawan pajak tentang materi intensifikasi.

Peningkatan pemahaman yang dijelaskan berdasarkan hasil kuisioner kepada relawan pajak menunjukkan adanya dampak positif dari kegiatan intensifikasi ini, sehingga kebermanfaatan kegiatan ini dapat dirasakan oleh relawan pajak. Relawan pajak akan mampu memberikan asistensi secara baik kepada wajib pajak dengan berbekal kegiatan intensifikasi, sehingga Dirjen pajak dalam hal ini akan terbantu dalam rangka melakukan pendampingan terhadap masyarakat.

Lebih lanjut, sistem e-biling merupakan salah satu upaya untuk meningkatkan kepatuhan wajib pajak untuk membayar pajak, sehingga tak ubahnya keberadaan relawan pajak juga bagian dalam rangka meningkatkan kepatuhan dan ketaatan memenuhi kewajiban perpajakan. Relawan pajak yang memiliki tingkat pemahaman cukup baik tentunya akan mampu memberikan asistensi secara baik pula dan pada akhirnya masyarakat akan welcome dengan keberadaan mereka baik dalam menyampaikan informasi tentang perpajakan ataupun dalam memenuhi kewajiban perpajakan seperti pelaporan SPT.

\section{Simpulan}

Kegiatan intensifikasi pemahaman pajak yang dilakukan kepada 14 orang relawan pajak Tax Center Universitas Wiraraja memberikan dampak yang positif, di mana tingkat pemahaman mereka mengalami perubahan dari sebelum mengikuti kegiatan dan setelah mengikuti kegiatan. Kenaikan tingkat pemahaman relawan pajak (yang lebih baik) akan memberikan kontribusi bagi mereka pada saat melakukan asistensi di masyarakat.

\section{Daftar Pustaka}

Resmi, S. (2019). Perpajakan: Teori \& Kasus (11th ed.). Jakarta: Salemba Empat.

Waluyo. (2017). Perpajakan Indonesia (11th ed.). Jakarta: Salemba Empat. 